\title{
Aliphatic Biomakerof Crude Oil from Juwata, Tarakan, North Kalimantan
}

\author{
Endah Mutiara Marhaeni Putri*, Eduardus Edi, R. Y. Perry Burhan,Yulfi Zetra, Agus Wahyudi and Zjahra \\ Vianita, \\ Department of Chemirstry, Institut Teknologi Sepuluh Nopember Surabaya \\ Jl. Arief Rahman Hakim, Sukolilo, Surabaya 60111, Indonesia \\ *Corresponding author, tel/fax:, +62-8113442558 / email: endah_mutiara@hotmail.com
}

\begin{abstract}
Characteristic organic geochemistry of crude oil Juwata, Tarakan, North Kalimantan provide information about the depositional sedimental environment and maturity of the oil. Crude oil was extracted with $n$-hexane (50: 2) for 24 hours to separate the crude oil with asphaltene, and if precipitation does not separate perfectly then centrifuged. Extracts were then refractionated using column chromatography according to the methods McCharty base. Fractionation results are obtained in the form of the neutral fraction, the acid fraction and polar fraction. Neutral fraction separated with KLTP method and aliphatic fraction and aromatic fractions. Aliphatic fraction subsequently analyzed by GC-MS. GC-MS analysis aliphatic fraction of n-alkanes in the form of compounds, and hopane, bikadinancompounds. The pattern of distribution of $n$-alkanes which consists of a range of $\mathrm{C}-17$ to $\mathrm{C}-33$. Carbon distribution with a range of $\mathrm{C}-21$ to $\mathrm{C}-33$ is dominating compared to the $\mathrm{C}_{-17}$ to $\mathrm{C}_{-20}$. This distribution pattern indicates the source of organic matter from terrestrial land wax component derived from higher plants. Hopane presence of compounds in crude oil aliphatic fractionsJuwata Tarakan, North Kalimantan analyzed by fragmentogram m/z = 191 . Hopane biomarker provide that information during the sedimentation stage diagenesis these compounds are degraded and stereochemical changes towards a stable isomer form, configuration changes $17 \alpha(\mathrm{H}), 21 \beta(\mathrm{H})$ during the process of diagenesis to a stable isomer which is $17 \alpha(\mathrm{H}), 21 \beta$ $(\mathrm{H})$ or $21 \beta(\mathrm{H}), 17 \alpha(\mathrm{H})$ indicates that oil comes from the old sediments. Biomarka bikadina identified according fragmentogram $\mathrm{m} / \mathrm{z}=191$ multiple ion fragment $\mathrm{m} / \mathrm{z}=109.191,369,397$ and ion molecular $\mathrm{m} / \mathrm{z}=412$ showed the characteristic fragment bikadinna compound. Biomarka bikadina give information influx of organic material terrestrial region. The compounds showed crude oils biomarker Juwata Tarakan, North Kalimantan derived from terrestrial depositional environments.
\end{abstract}

Keywords - Biomarkers, crude Juwata, GCMS

\section{INTRODUCTION}

Crude oil is one of the world's energy resources. Crude oil is an extremely complex mixture of organic chemicals containing carbon, hydrogen and oxygen as the main element, as well as sulfur and nitrogen as an additional element. The quality of crude oil is determined by several factors, including the presence of a basin, age and the amount of contamination. Chemical properties and the physics of a crude oil is determined by the mechanism of its formation. The need for petroleum energy each year increase is not matched by an increase in production led to Indonesia threatened by an energy crisis. Therefore, it is necessary exploration efforts to find new oil sources so that the threat of an energy crisis can be resolved. Juwata is one of the sub-fields of petroleum Tarakan Basin is geographically located approximately 240 kilometers north-up northeast of Balikpapan. Exploratory oil wells TarakanJuwata North Borneo in 2013 by PT Pertamina unit V Tarakan has gone through a preliminary investigation that detailed, among other things concerning the geological and geophysical surveys. Organic geochemistry investigation which is a new parameter not yet done so informasih the organic material composition, origin, and the maturity level of the 
oil can not be reported. Therefore, it is necessary to organic geochemical characterization through profiles biomarka compounds to determine the maturity of oil, their biodegradation, migration in sediments and petroleum, the origin of organic material, depositional environment and the quality of the oil.

\section{EXPERIMENTAL SECTION}

\subsection{Material}

Crude oil from Tarakan island, Kalimantan, Nitrogen gas, Filter paper, Aluminium foil, Cotton, Scissors, Sand, Silica gel GF 254 , Deionised water, Cellite, 1,2,5,6-dybenzantrasena (DBA), N-hexane, Dicloromethane, Asethon, Chloroform, Methanol, Dyethileether, acetic acetate.

\subsection{Method}

Samples of crude oil was separated using a separating funnel for separating water and oil. 2 grams samples of free water to be reconstituted with the solvent n-hexane in the ratio of oil with n-hexane (2:50) and precipitated for 24 hours at room temperature for separating the asphalt and oils, if did not separated, the precipitated asphalt oil ought to centrifugated. The results of centrifugation filtered and evaporated the solvent using a rotary vacuum evaporator and then transferred into a vial bottle. The dry extract was weighed and stored for subsequent analysis.

Extracts Organic matters (EOM)pure crude oil was separated by column liquid chromatography into neutral fraction using diethyl ether [1]. Neutral fraction was separated by Thin Layer Chromatography (TLC) with DCM into Alcohol, Ketone and Hidrocarbon fractions. Furthermore, Hidrocarbon fraction was separated by Thin Layer Chromatography (TLC) with Hexane intoAlifatic and Aromatic fractions with the value of Rf 1.0 to 0.9 and aromatics $\mathrm{Rf} 0.9$ to 0.1 [2].

\subsection{Characterizations}

Alifatic fractions analyzed by gas chromatography - mass spectrometry (GC-MS) were taken out agilent 122-5561 equipped with DB-5 fused capillary silica column $(60 \mathrm{~m} \times 0.25 \mathrm{~mm})$, using helium as carrier gas. The oven temperature were set up at $40^{\circ} \mathrm{C}(2 \mathrm{~min}$ hold $), 40^{\circ} \mathrm{C}-100^{\circ} \mathrm{C}$ at $10^{\circ} \mathrm{C} / \mathrm{min}$, then $100-290^{\circ} \mathrm{C}$ at $4^{\circ} \mathrm{C} / \mathrm{min}$ and $290^{\circ} \mathrm{C}$ (30 min hold). Massspectrometry was operated $70 \mathrm{eV}$ ionization voltageand $230^{\circ} \mathrm{C}$ interface temperature.

\section{RESULTS AND DISCUSSION}

\subsection{Composition of hydrocarbon compounds ofalifatic}

The result of GC-MS from hydrocarbon compounds of aliphatic fraction was showed in Fig.1.

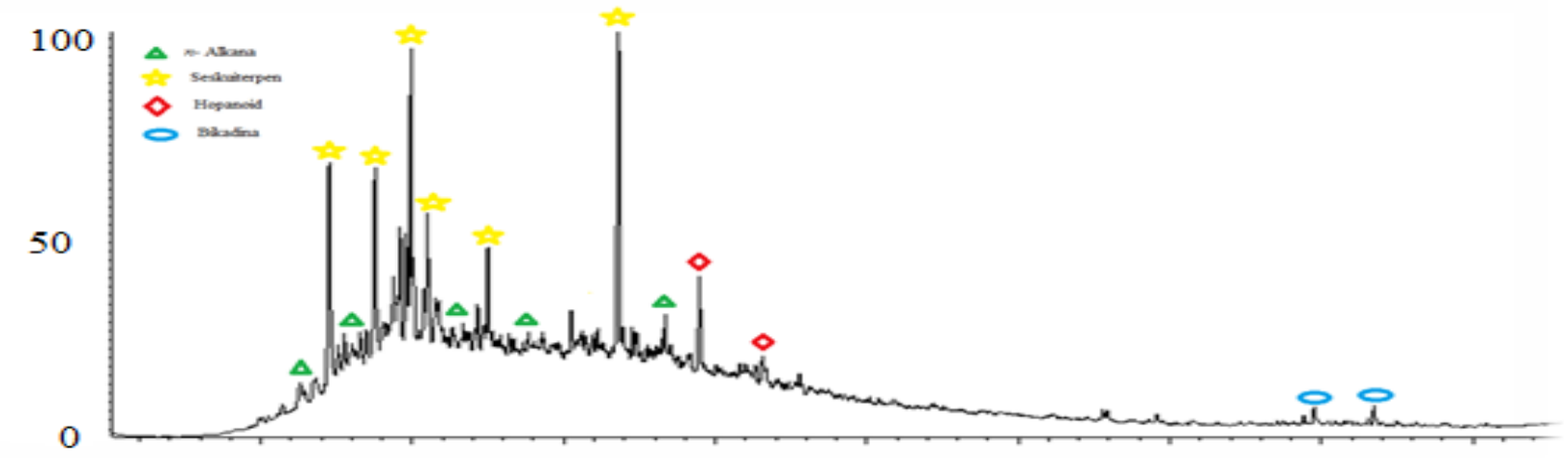

Figure 1 Chromatogram of aliphatic fraction hydrocarboncompounds of crude oil Juwata Tarakan, North Kalimantan 


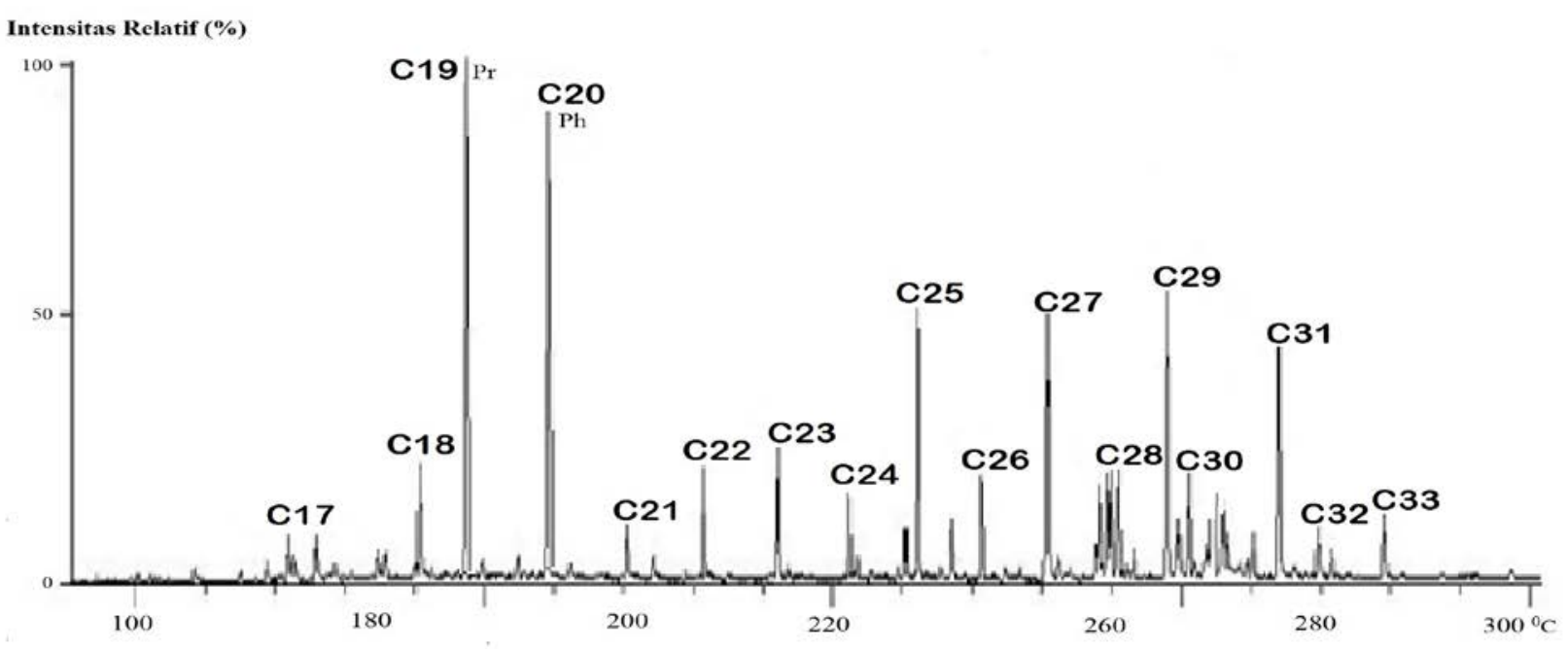

Figure 2 The fragmentogram $\mathrm{m} / \mathrm{z} 57$ of aliphatic fraction n-alkane hydrocarbon compounds of crude oilJuwataTarakan, North Kalimantan

\section{2. n-alkane Compounds}

The existence of n-alkane compounds in aliphatic fraction were identified by $57 \mathrm{~m} / \mathrm{z}$ fragmentogramwas basic peak of alkane compounds. It was identified due to releasing of (C4H9)+ groups. The fragmentogram of $57 \mathrm{~m} / \mathrm{z}$ of aliphatic hydrocarbon fraction JuwataTarakanwasshowenin Fig. 2.

Crude oil Juwata Tarakan, North Kalimantan also found homologous compounds of long-chain n-alkanes $\mathrm{C}_{21}-\mathrm{C}_{35}$ dominated by odd carbon atoms and a maximum peak is at $\mathrm{C}_{29}$. Stojanovic and Zivotic states that if the identified n-alkanes with a range of carbon $\mathrm{C}_{21}-\mathrm{C}_{30}$ in a sediment, where the maximum peak is located at $\mathrm{C}_{27}$ or $\mathrm{C}_{29}$ and there is a predominance of carbon odd to carbon even, significantly shows the contribution of apikultikular wax as the organic material sedimentary. In contrast to the distribution of long-chain n-alkanes are dominated by $\mathrm{C}_{21}-\mathrm{C}_{25}$, the source of the sediment organic matter derived from vascular plants, microalgae, cyanobacteria, sphagnum and aquatic microorganisms, especially macrophytes. Tissot and Welte also stated that the compounds homologous n-alkanes $\mathrm{C}_{25}-\mathrm{C}_{35}$ is a marker compound for resources sedimentary organic matter derived from plant wax coating high level. The same thing also expressed by Eglinton and Hamilton in his research stating that the hydrocarbon n-alkanes $\mathrm{C}_{29}-\mathrm{C}_{31}$ is a marker compound for terrestrial plants. In the study also mentioned if the presence of n-alkane chain length with an abundance maximum at $\mathrm{C}_{27}, \mathrm{C}_{29}$ and $\mathrm{C}_{31}$, as well as their dominance of the carbon atom odd, indicates that it is generally the source of organic matter derived from higher plants mainland.

The distribution pattern of n-alkane compounds can also demonstrate the maturity of a sediment. Old sediments, such as sediments deposited at the end of the Archean, generally have a distribution of n-alkanes dominated homologous short chain n-alkanes. Extracts from sediments immature usually have an abundance amount of carbon even very low, but with the increase in the level of maturity, the number of carbon atoms even be formed through a process diagenetik of aliphatic hydrocarbon contained in kerogen or alcohols, esters and alkanes other. Crude oil from Juwata Tarakan, North Kalimantan identified n-alkanes in the $\mathrm{C}_{17^{-}}$ $\mathrm{C}_{33}$ range dominated by long chains of carbon atoms in which the carbon to carbon dominant odd even, then it can be concluded that crude oil is the oil that has the maturity level of being.

\subsection{Hopanoid}

The existence of derivatives aliphatic compounds Hopanoid in crude oil fractions Juwata Tarakan, North Kalimantan analyzed by fragmentogram m/z 191 are shown in the following figure 3. 


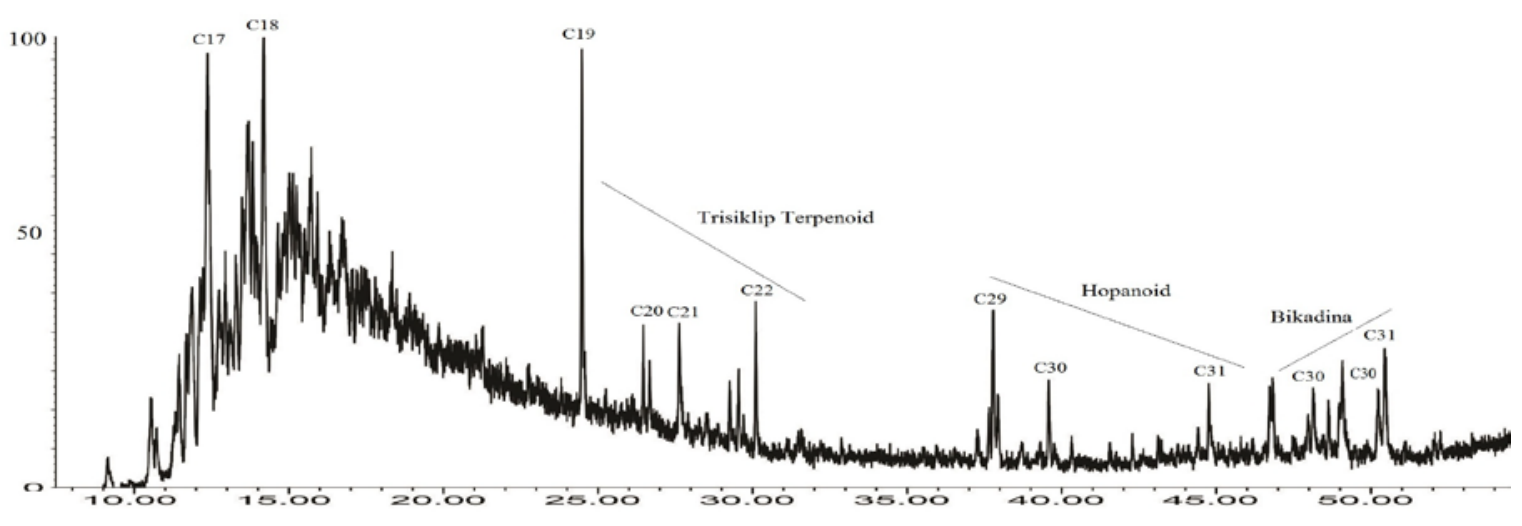

Figure 4 The fragmentogram m/z 191 of aliphatic fractionhopanoid hydrocarbon compounds of crude oilJuwata -Tarakan, North Kalimantan.

Hopanoid biomarka a group of compounds found in sediments. These compounds are generally derived from bacteria, although this compound is also found in moss, fungi, algae and various types of higher plants.As hopanoid compounds found in crude oil Juwata, Tarakan is $17 \alpha(\mathrm{H}), 21 \beta$-norhopan, $17 \alpha(\mathrm{H}), 21 \beta$ hopan and $17 \alpha(\mathrm{H}), 21 \beta$-homohopan the Figure 4. The existence of these compounds homologous to the crude oil Juwata Tarakan, North Kalimantan indicating their contribution sedimentary organic matter derived from bacteria heterotrof and sianobactery phototrofic. Hopanoid compound is a product of the biosynthesis of sulfate reducing bacteria, especially the genus Deusulfovibrio in anoxic conditions. The bacteriacontaining compounds in the form hopanoid diploten, diplopterol, bakteriohopanetetrol, 35-aminotriol, 35and 35-aminopentol aminotetrol. Identification of compounds homologous hopan long chain $\left(>\mathrm{C}_{30}\right)$ comes from bakteriohopanatetrol contained in the bacterial membrane prokaryotic (Peters and Moldowan, 1993), whereas the homologous hopan $\mathrm{C}_{29}-\mathrm{C}_{31}$ indicates that the compound is derived from biohopanoid diploten and diplopterol for having 30 carbon atoms or less, Further analysis of the presence of hopane compounds in crude oil Juwata Tarakan, North Kalimantan can provide that information during the sedimentation stage diagenesis these compounds are degraded and stereochemical changes towards a stable isomer forms. Configuration changes $17 \alpha(\mathrm{H}), 21 \beta(\mathrm{H})$ during the process of diagenesis to isomer stable at $17 \alpha(\mathrm{H}), 21 \beta(\mathrm{H})$ or $21 \beta(\mathrm{H}), 17 \alpha(\mathrm{H})$ indicates that the oil is derived from maturity sediments and already overcooked. (RiesKautt and Albercht, 1998).

\subsection{Bikadines}

Analysis bikadinana biomarka compounds identified in accordance fragmentogram m / z 191 as shown in Figure 4.Fragment ions characteristic of compounds biomarka bikadina $\mathrm{m} / \mathrm{z}=109.191,369,397$ and molecular ion $\mathrm{m} / \mathrm{z}=412$. The presence of aliphatic compounds bikadina on crude oil fractions Juwata Tarakan, North Kalimantan indicates that the sample is derived from plant oils terestrstial that of resin level plant resin. The study conducted by Pearson and Alam, et al., (1990) reported that bikadina compound belonging to the class of pentacyclic triterpenoids. This compound is contained in the resin. A strong indication that the compound bikadina resins derived from it according to the physical characteristics of Crude Oils, Juwata - Tarakan, North Kalimantan is aromatic compound [3].

\section{Conclusion}

Based on the results of analysis of coal samples Juwata Tarakan North Sumatra basin, there is a pattern of the spread of n-alkane compounds that are similar from both samples, results of interpretation showed the presence of total ion chromatogram distribution of $\mathrm{n}$-alkanes compound $\mathrm{nC}_{17}-\mathrm{nC}_{33}$. Distribution of n-alkanes compound $\mathrm{nC}_{17}-\mathrm{nC}_{20}$ show the contributions of compounds from algae and cyanobacteria, while the distribution of $\mathrm{n}$-alkanes compounds $\mathrm{nC}_{21}-\mathrm{nC}_{33}$ indicates the contribution of high level plant compounds. With an abundance of exclusive $\mathrm{C}_{27}$ compound showed that the dominant contribution of higher plants compounds. 
As hopanoid compounds found in crude oil Juwata, Tarakan is $17 \alpha(\mathrm{H}), 21 \beta$-norhopan, $17 \alpha(\mathrm{H}), 21 \beta$ hopan and $17 \alpha(\mathrm{H}), 21 \beta$-homohopan

\section{REFERENCES}

[1] R. D. Mccarthy and A. H. Duthie, "A rapid quantitative method for the separation of free fatty acids from other lipids,” J. Lipid Res., vol. 3, no. 1, 1962.

[2] R. Y. P. Burhan, J. M. Trendel, P. Adam, P. Wehrung, P. Albrecht, and A. Nissenbaum, "Fossil bacterial ecosystem at methane seeps: Origin of organic matter from Be'eri sulfur deposit, Israel,” Geochim. Cosmochim. Acta, vol. 66, no. 23, pp. 4085-4101, Dec. 2002.

[3] M. J. Pearson and M. Alam, "Bicadinanes and other terrestrial terpenoids in immature Oligocene sedimentary rocks and a related oil from the Surma Basin, N.E. Bangladesh,” Org. Geochem., vol. 20, no. 5, pp. 539-554, Jul. 1993. 